\title{
Corrigendum: Reviewing School Uniform Through a Public Health Lens: Evidence About the Impacts of School Uniform on Education and Health
}

\author{
Johanna Reidy* \\ Department of Public Health, Wellington School of Medicine, University of Otago, Wellington, New Zealand
}

Keywords: school uniform, public health, equity, health impacts, education impacts, human rights

\section{A Corrigendum on}

Reviewing School Uniform Through a Public Health Lens: Evidence About the Impacts of School Uniform on Education and Health

by Reidy, J. (2021). Public Health Rev. 42:1604212. doi: 10.3389/phrs.2021.1604212

In the original article, there was a mistake in Table 2 as published. "Health and Safety can be enhanced by uniform design" should have been placed in the "Positive impact" column, not the "Neutral impact" column. "Non-inclusive design can reduce girls' and overweight students' confidence to participate in sport; Bullying and social exclusion for uniform following rules; Inflexible uniform policy harmful for gender-diverse students." was placed in the "Neutral impact" column, and should be in the "Negative impact" column. In all parts of the table semicolons were incorrectly changed to full stops. The corrected Table 2 appears below.

In the original article, there was an error. "and socio-cultural contexts which inform uniform use" was incorrectly written as "and socio-cultural context in which inform uniform is used."

A correction has been made to Results, first paragraph, final sentence:

"Here, evidence has been arranged according to a public health lens of analysis. First, this section

OPEN ACCESS

Approved by:

Public Health Reviews Editorial Office, Frontiers Media SA, Switzerland

*Correspondence: Johanna Reidy johanna.reidy@otago.ac.nz

Received: 21 October 2021 Accepted: 26 October 2021 Published: 13 December 2021

Citation:

Reidy J (2021) Corrigendum: Reviewing School Uniform Through a Public Health Lens: Evidence About the Impacts of School Uniform on

Education and Health.

Public Health Rev 42:1604543. doi: 10.3389/phrs.2021.1604543 examines the proximate educational and health impacts of uniform garments and uniform policy on students to determine whether there are immediate health or education impacts of uniform use or policy. Second, rationales for uniform use are examined, as well as distal factors that influence student experience. This section examines the broader institutional, and socio-cultural contexts which inform uniform use."

In the original article, there was an error. The word "is" was missing.

A correction has been made to Part 1: Literature for Educational and Health Impacts of Uniform; Does Uniform Influence Educational Outcomes? First sentence:

"Starting with the evidence for the impact of uniform on educational outcomes (the core in Figure 1), there is little convincing evidence that uniform improves academic achievement."

In the original article, there was an error. The word "as" was missing.

A correction has been made to Part 3: Human Rights and Uniform Use; Uniform and Freedom of Religion, paragraph 3, first sentence:

"Whatever the social context, outward signs of faith can challenge both uniform rules and wider societal values such as secularity in public institutions."

In the original article, there was an error. The word "has" was missing.

A correction has been made to Discussion, paragraph 5, second sentence:

"This review has highlighted that uniform has become a proxy for many issues." 
TABLE 2 | Uniform's positive, neutral, and negative impacts on education and health outcomes.

\begin{tabular}{|c|c|c|c|}
\hline Domain & Positive impact & Neutral impact & Negative impact \\
\hline $\begin{array}{l}\text { Educational } \\
\text { outcome }\end{array}$ & $\begin{array}{l}\text { Improves classroom management; faster settling to task; } \\
\text { reduced distractions }\end{array}$ & $\begin{array}{l}\text { No clear impact on } \\
\text { academic achievement }\end{array}$ & $\begin{array}{l}\text { Detracts/distracts from teacher-student rapport; Reduces } \\
\text { creativity in population; An extra barrier to socialisation for } \\
\text { newcomers/minorities }\end{array}$ \\
\hline $\begin{array}{l}\text { Health outcomes: } \\
\text { Physical }\end{array}$ & $\begin{array}{l}\text { Insecticide-treated uniform can provide protection against } \\
\text { dengue; Well-designed uniform can protect skin from sun } \\
\text { damage; Health and safety can be enhanced in uniform } \\
\text { design }\end{array}$ & & $\begin{array}{l}\text { Poor uniform policy a barrier to incidental and curriculum } \\
\text { based exercise; Poor uniform design a barrier for incidental } \\
\text { exercise, especially for girls; Sun protection not considered } \\
\text { in policy or garment design; Physical comfort/health not } \\
\text { prioritised in design; Health and safety can be misapplied to } \\
\text { ban certain non-uniform items }\end{array}$ \\
\hline $\begin{array}{l}\text { Health outcomes: } \\
\text { Psychosocial }\end{array}$ & $\begin{array}{l}\text { Unisex and inclusive design can increase girls' and } \\
\text { overweight students' confidence to participate in sport; } \\
\text { Self-esteem promoted (if student can afford full and } \\
\text { correct uniform); Removes competitive dressing pressure; } \\
\text { Decreases bullying }\end{array}$ & & $\begin{array}{l}\text { Non-inclusive design can reduce girls' and overweight } \\
\text { students' confidence to participate in sport; Bullying and } \\
\text { social exclusion for following uniform rules; Inflexible uniform } \\
\text { policy harmful for gender-diverse students }\end{array}$ \\
\hline
\end{tabular}

In the original article, there was an error. The word "it" was used in place of the word "if".

A correction has been made to Discussion, paragraph 6, final sentence:

"It has also shown that uniform merits public health interest: if uniform use is prevalent, its use impacts on health and educational outcomes, and, importantly, school uniform garments and policies regulating their use are amenable to improvement, with an eye to improving equity."

In the original article, there was an error. The word "use" was incorrectly placed after the parenthesis.

A correction has been made to Discussion, paragraph 7, sentence 7:

"For instance, the physical impacts of uniform use (e.g., on physical activity of wearers, protection against environmental hazards) were measured using quantitative or qualitative/ quantitative mixes of design with larger sample sizes."
In the original article, there was an error. "has school uniform" was incorrectly included in a sentence.

A correction has been made to Conclusion, third sentence:

"Yet uniform use has real impacts on health and education, for better and for worse."

The author apologizes for these errors and states that this does not change the scientific conclusions of the article in any way. The original article has been updated.

Copyright $\odot 2021$ Reidy. This is an open-access article distributed under the terms of the Creative Commons Attribution License (CC BY). The use, distribution or reproduction in other forums is permitted, provided the original author(s) and the copyright owner(s) are credited and that the original publication in this journal is cited, in accordance with accepted academic practice. No use, distribution or reproduction is permitted which does not comply with these terms.

PHR is edited by the Swiss School of Public Health (SSPH+) in a partnership with the Association of Schools of Public Health of the European Region (ASPHER)+ 